\title{
GEORGE GRANT AND THE THEOLOGY OF THE CROSS
}

The Christian Foundations of His Thought 
This page intentionally left blank 


\section{George Grant and the Theology of the Cross}

The Christian Foundations of His Thought

HARRIS ATHANASIADIS

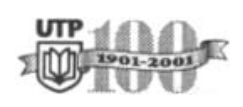

UNIVERSITY OF TORONTO PRESS

Toronto Buffalo London 
www.utppublishing.com

(C) University of Toronto Press Incorporated 2001

Toronto Buffalo London

Printed in Canada

ISBN 0-8020-4875-7

(6)

Printed on acid-free paper

\section{Canadian Cataloguing in Publication Data}

\section{Athanasiadis, Harris}

George Grant and the theology of the cross : the Christian foundations of his thought

Includes bibliographical references and index.

ISBN 0-8020-4875-7

1. Grant, George, 1918-1988 - Contributions in theology.

2. Philosophical theology. I. Title.

B995.G74A83 $2000 \quad 191 \quad$ C00-932249-3

University of Toronto Press acknowledges the financial assistance to its publishing program of the Canada Council for the Arts and the Ontario Arts Council.

This book has been published with the help of a grant from the Humanities and Social Sciences Federation of Canada, using funds provided by the Social Sciences and Humanities Research Council of Canada.

University of Toronto Press acknowledges the financial support for its publishing activities of the Government of Canada through the Book Publishing Industry Development Program (BPIDP). 
To my mother, Anna,

whose emotional and spiritual influence has formed the ground upon which I stand

my wife, Leanna,

whose nurture, support, and encouragement have become a daily source of sustenance

and my children, Hannah and Mark,

who both in their uniqueness of being have taught me what it means

to consent to the way of the cross 
This page intentionally left blank 